DOI 10.18551/rjoas.2021-12.26

\title{
THE COMPOSITION AND ABUNDANCE OF PLANKTON AS NATURAL FISH FOOD IN THE BARITO RIVER OF MARABAHAN DISTRICT, BARITO KUALA REGENCY, INDONESIA
}

\author{
Rahman Abdur*, Yasmi Zairina \\ Study Program of Water Resources Management, Faculty of Fisheries and Marine Sciences, \\ University of Lambung Mangkurat, South Kalimantan, Indonesia
Maya
Study Program of Aquatic Resources Management, Faculty of Fisheries and Marine Sciences, University of Lambung Mangkurat, South Kalimantan, Indonesia

\author{
Sofarini Dini \\ Study Program of Water Resources Management, Faculty of Fisheries and Marine Sciences, \\ University of Lambung Mangkurat, South Kalimantan, Indonesia \\ Khasanah Ruly Isfatul, Munir Misbakhul \\ Study Program of Marine Science, Faculty of Science and Technology, University of Islam \\ Negeri Sunan Ampel Surabaya, Surabaya, Indonesia \\ *E-mail: rahmantrk@gmail.com
}

\begin{abstract}
The purpose of this study is to determine the level of fertility of the waters in the Barito River so that it can be used sustainably and the quality of the Barito River's water ecosystem is maintained. The research was conducted in the Barito River, Marabahan District, Barito Kuala Regency. Sampling was carried out 3 times in May - June 2021. Sampling was carried out at two stations, namely upstream and downstream of the Barito River. Nutrient conditions in Barito River waters show differences between stations and between sampling times. Overall, station 2 which is located downstream of the river has a higher content than station 1 , both for nitrate and phosphate parameters. The opposite result is shown in the abundance of plankton in the waters where station 1 has a higher abundance than station 2 at all sampling times. The relationship between the two variables was then carried out by a simple regression test which showed that the nitrate parameter had a linear relationship to the abundance of plankton with a low-medium relationship. Different results are shown by the phosphate parameters where there is an opposite, namely if the phosphate decreases, the abundance of plankton will increase with a moderate-strong relationship. In addition, the results of the analysis of the fish choice index $(E)$ show that fish have a preference for their food. This is evidenced by the presence of some fish eating organisms that are not found in their environment but are found in their stomachs.
\end{abstract}

\section{KEY WORDS}

Abundance, phytoplankton, stomach contents, Barito, South Kalimantan.

The existence of plankton in a waters can provide information about the condition of the waters. Plankton is used as a bioindicator of water conditions because plankton has tolerance limits to certain substances (Faza, 2012). Phytoplankton as a biological indicator can determine the quality of the waters either through the approach of species diversity or indicator species. Phytoplankton as a biological indicator not only determines the level of water fertility, but also the phase of pollution that occurs in the waters (Elfinurfajri, 2009).

The abundance of phytoplankton in waters depends on the content of nutrients in the waters, including nitrate and phosphate. The concentration of nitrate and phosphate in waters is influenced by the quality of the water and the discharge of waste that enters a river. 
The river is an aquatic ecosystem that plays an important role in the hydrological cycle and functions as a catchment area for the surrounding area. As an ecosystem, river waters are composed of various biotic and abiotic components that interact and influence each other. Components in the river ecosystem will be integrated with each other to form an energy flow that will support the stability of the ecosystem (Suwondo, et al., 2004).

The Barito River is an ecosystem that is important for the life of living things and the surrounding environment. Rivers provide benefits for human life in the vicinity and the life of organisms in the waters. The role of rivers for human activities is related to the life of organisms. The existence of human activities that utilize river waters does not only have an impact on the life of organisms but also on the quality of the river water.

In this regard, a study was conducted that aims to determine the type composition and abundance of plankton as natural fish feed in the Barito River, Marabahan District, Barito Kuala Regency. This research is important to determine the level of water fertility in the Barito River so that it can be used sustainably and the quality of the aquatic ecosystem is maintained.

\section{METHODS OF RESEARCH}

The research was conducted in the Barito River, Marabahan District, Barito Kuala Regency. Sampling was carried out 3 times in May - June 2021. Sampling was carried out at two stations, namely upstream and downstream of the Barito River.

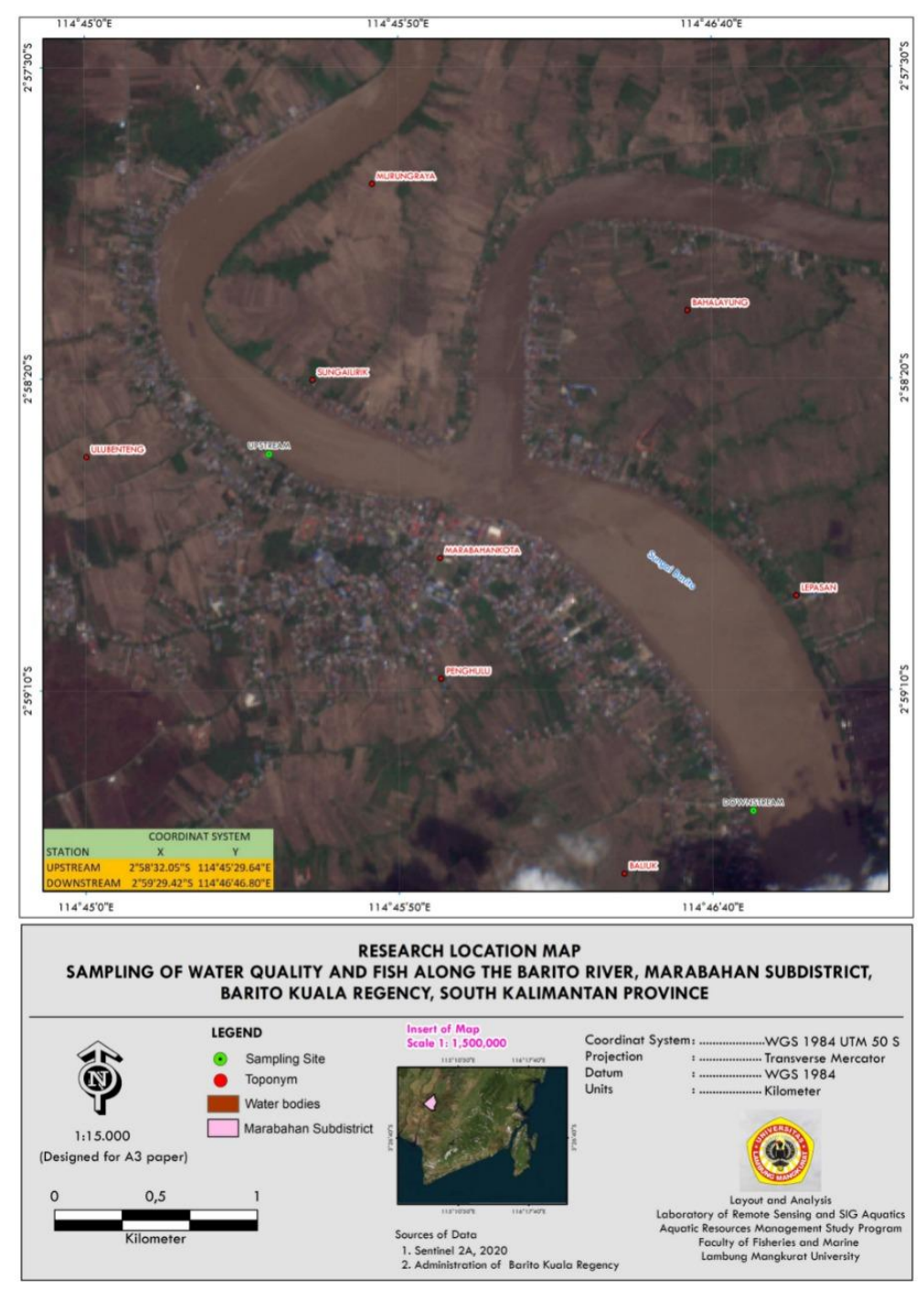

Figure 1 - Research location 
The tools and materials used in this study are divided into two, namely the tools and materials used during sampling and sample observation. The tools and materials used during data collection are presented in Table 1. Meanwhile, the tools and materials used for observing plankton samples are presented in Table 2.

Table 1 - Tools and materials used in plankton sampling

\begin{tabular}{lll}
\hline \multicolumn{2}{l}{ Sampling } & \\
\hline No & Tools and Materials & Function \\
\hline 1 & Plankton net & Used to take plankton samples \\
2 & Sprayer & To spray plankton attached to the plankton-net \\
3 & Sample bottle & To accommodate plankton samples (sample containers) \\
4 & Coolbox & To store plankton samples \\
5 & GPS & Used to determine the coordinates of the sampling location \\
6 & DO meter & To measure $\mathrm{DO}$ and water temperature \\
7 & refractometer & To measure the pH and salinity of water \\
8 & secchi disk & To measure water brightness \\
9 & Drop pipette & To take lugol \\
10 & Lugol & For plankton sample preparation \\
11 & Stationary & Used to record the measurement results of water physico-chemical parameters \\
12 & Net & To catch fish \\
\hline
\end{tabular}

Table 2 - Tools and materials used in sample observation

\begin{tabular}{lll}
\hline Sample Observation & \\
\hline No & Tools and Materials & Function \\
\hline 1 & Microscope & To observe plankton samples \\
2 & SRCC (Sedgwick-Rafter Counting Cell) & Used as a sample to be observed \\
3 & Drop pipette & Used to take plankton samples \\
4 & Plankton Samples & Samples to be observed \\
5 & Measuring Tube & To measure sample volume \\
6 & Stationary & To record plankton observations \\
7 & Aquades and Tissue & To clean the Sedgwick-Rafter Counting Cell (SRCC) \\
8 & Identification Book & As a guide to identify plankton \\
9 & Camera or Mobile & Used to take photos of plankton observations \\
10 & Secchioset & To dissect the entrails of fish \\
\hline
\end{tabular}

Sampling was carried out every two weeks as much as 3 times at each observation station. Sampling of plankton was carried out at each station by taking 25 liters of water and then filtered using plankton net no. 25. The remaining volume is $50 \mathrm{ml}$ then put into a sample bottle. then preserved with 4-6 drops of Lugol's solution in each sample bottle, then each sample bottle is labeled. Then identification of plankton was carried out under a microscope and assisted by identification books from Needham (1962), Edmondson (1963) and Mizuno (1979).

Nekton sampling was carried out simultaneously with plankton sampling. Nekton samples were taken using a fishing net with a mesh size of 1 inch. The nekton obtained was then put into a $5 \mathrm{~kg}$ plastic bag and preserved in $10 \%$ formalin to avoid the spoilage process. The nekton samples were identified in the Integrated Laboratory of the Aquatic Resources Management Study Program, Lambung Mangkurat University, using the identification book of Kottelat et al. (1993) and Needham \& Needham (1992).

Sampling of water for this nutrient parameter is taken as much as 1 liter. These nutrients include measurements of nitrate and phosphate whose tests were carried out in the Environmental Laboratory of the Faculty of Fisheries and Marine ULM.

Before the plankton sample was observed, the sample volume was measured using a measuring tube. Volume measurement results obtained are recorded for data analysis purposes. The plankton samples obtained were identified using a microscope. For identification purposes, $1-1.5 \mathrm{ml}$ plankton samples were taken using a dropper and then placed in the Sedgwick Rafter Counting Cell (SRCC) which was then observed using a microscope (Rachman et. al. 2018). Plankton samples were identified by the identification table method. 
The identification table method is the observation of plankton samples using a microscope to determine the genus and number of plankton found in the sample. Furthermore, the plankton genera found were identified and counted and then entered into the observation table (an example of an observation table can be seen in Appendix 2). Meanwhile, plankton samples were identified by referring to the identification books of Shirota (1966), Tomas (1997) and Yamaji (1979).

To determine the amount of plankton contained in a waters at each volume, the abundance of plankton was calculated. The abundance of plankton is the number of plankton individuals/cells in a particular unit of water (cells/L or ind/L). Analysis of the abundance of plankton (N) can be calculated using the formula APHA (1989) (Equation [1]).

$$
N=\left(\frac{O i}{O p} \times \frac{V r}{V o} \times \frac{1}{V s} \times \frac{n}{p}\right)
$$

Where: $\mathrm{N}=$ Number of cells per liter (cells/liter); Oi = Area of the cover glass $\left(\mathrm{mm}^{2}\right)$; $\mathrm{Op}=$ Area of one field of view $\left(\mathrm{mm}^{2}\right) ; \mathrm{Vr}=$ Volume of filtered water $(\mathrm{ml}) ; \mathrm{Vo}=$ Volume of sample under cover glass $(\mathrm{ml}) ; \mathrm{Vs}=$ Volume of filtered seawater sample $(\mathrm{L}) ; \mathrm{n}=$ Number of phytoplankton cells in the entire field of view (cells); $p=$ Number of fields observed $\left(\mathrm{mm}^{2}\right)$.

According to Odum (1996), the abundance of phytoplankton can indicate an indicator of the fertility of a waters. Water fertility based on the abundance of phytoplankton can be seen in Table 3.

Table 3 - Fertility of waters based on abundance of phytoplankton

\begin{tabular}{ll}
\hline Abundance $(\mathrm{N})$ & Category \\
\hline$>500 \mathrm{cell} / \mathrm{L}$ & high water fertility \\
$<500 \mathrm{cell} / \mathrm{L}$ & moderate water fertility \\
\hline
\end{tabular}

According to Sri Artiningsih (2013) the diversity index is often referred to as diversity index. This analysis is used to determine the diversity of aquatic biota species. To determine the value of diversity can use the Shanon-Wiener diversity index (Odum, 1993) with Equation 2.

$$
H^{\prime}=-\sum_{i=0}^{i} P i \ln P i
$$

Where: $\mathrm{H}^{\prime}=$ diversity index; $\mathrm{Pi}=\mathrm{ni} / \mathrm{N} ; \mathrm{ni}=$ Number of individuals of type I; $\mathrm{N}=$ Total number of individuals.

The diversity index value $\left(\mathrm{H}^{\prime}\right)$ according to the Shannon-Wiener equation is classified in Table 4 (Odum, 1993).

Table 4 - Shannon-Wiener Diversity Index

\begin{tabular}{ll}
\hline Diversity $\left(\mathrm{H}^{\prime}\right)$ & Category \\
\hline $0<\mathrm{H}^{\prime}<2,3$ & low level of diversity \\
\hline $2,3<\mathrm{H}^{\prime}<6,9$ & medium level of diversity \\
\hline $\mathrm{H}^{\prime}>6,9$ & high level of diversity \\
\hline
\end{tabular}

Twenty fishes caught in the Barito River were taken to determine the average body length of the fish. Then the stomach was taken to analyze the composition of phytoplankton and zooplankton in it and to determine the level of preference (index of choice) of these fish in choosing food.

The amount of plankton found in the fish's stomach was calculated by the volumetric method while the composition of the food was calculated by the index of preponderance (Ivlev, 1961).

The composition of plankton contained in the fish stomach is compared to that found in the waters, in the form of an absent-present table, namely:

1. Components of plankton contained in the stomach of fish in the waters;

2. Plankton components in the stomach but not in the water; 
3. Plankton components that are not found in the fish stomach but are found in the waters.

To determine the type of plankton which is the main choice for fish food, an index of electivity analysis was carried out by comparing the amount of plankton contained in the fish stomach with the abundance of plankton species in the waters with the formula (Ivlev, 1961):

$$
E=\frac{r_{i}-p_{i}}{r_{i}+p_{i}}
$$

Where: $\mathrm{E}=$ Preferred Index; $\mathrm{ri}=$ The relative number of types of organisms eaten; $\mathrm{pi}=$ The relative number of organisms in the water.

The value of the index of choice $(E)$ ranges from -1 to +1 , which indicates that the closer to +1 , a type of plankton is the main choice of fish food.

\section{RESULTS AND DISCUSION}

Nutrients are essential elements that are very important for the growth of the plankton community in waters. According to Ambarwati (2019) that nutrients in a water have an influence on the abundance of plankton. The following are the results of measurements of nitrate and phosphate in Barito River waters as shown in Table 5.

Table 5 - Results of nitrate and phosphate measurements

\begin{tabular}{|l|l|l|l|l|}
\hline Sampling & Month & Station & Nitrate & Phosphate \\
\hline \multirow{2}{*}{1} & \multirow{2}{*}{ April } & I & 0.1 & 0.45 \\
\cline { 3 - 5 } & & II & 0.1 & 0.6 \\
\hline \multirow{2}{*}{2} & \multirow{2}{*}{ May } & I & 0.05 & 0.37 \\
\cline { 3 - 5 } & \multirow{2}{*}{3} & II & 0.14 & 0.38 \\
\cline { 3 - 5 } & \multirow{2}{*}{ June } & II & 0.45 & 0.01 \\
\hline
\end{tabular}

Note: ST 1 - Ulu Fort (upstream of the Barito River); ST 2 - Rumpiang (downstream of the Barito River).
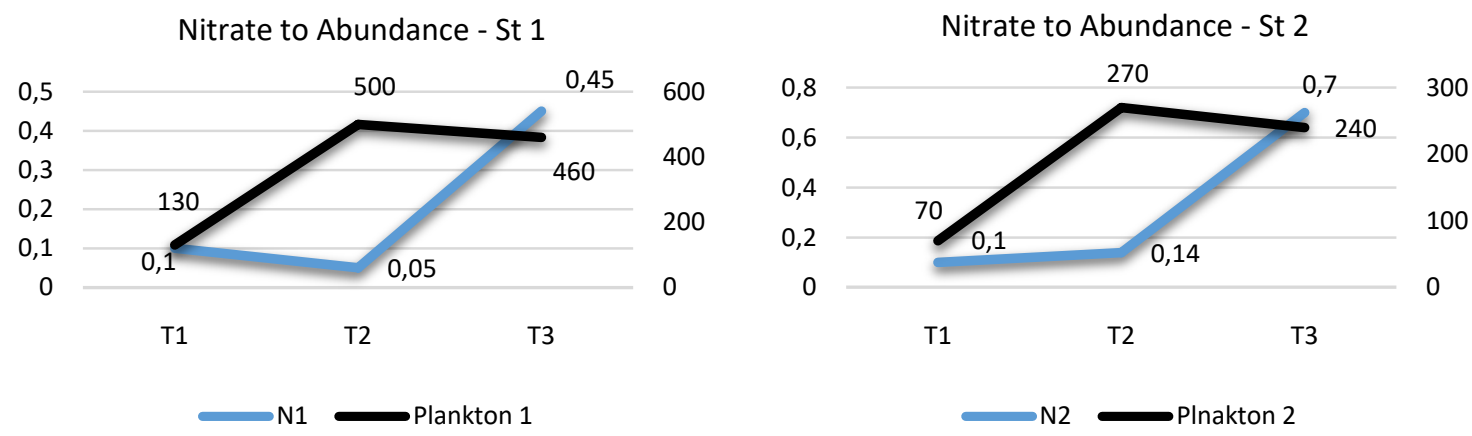

Figure 2 - Results of measurements of nitrate levels in the waters

The results of testing the nitrate and phosphate parameters in the Barito River waters show varied values. The nitrate parameter has a value that ranges from $0.05-0.7 \mathrm{mg} / \mathrm{l}$ with the highest value found at the 3rd sampling station. Based on PP No. 82 of 2001 concerning Water Quality Management and Pollution Control on the classification and criteria of class II wastewater quality standards for freshwater biota, the threshold value of nitrate in waters is $10 \mathrm{mg} / \mathrm{L}$. The high nitrate at this station is thought to be due to its location downstream of the river where it has a high sedimentation rate so that the nutrient content increases. The nitrate results obtained during the test were far below the specified quality standard, which means that the nitrate value at the study site was in the range that supported the growth and development of phytoplankton. The nitrate concentration at the study site was in the range of 0-1 $\mathrm{mg} / \mathrm{L}$, indicating that the waters belonged to oligotrophic waters. (Effendi, 2003) stated 
that oligotrophic waters have nitrate concentrations between $0-1 \mathrm{mg} / \mathrm{L}$, mesotrophic waters of $1-5 \mathrm{mg} / \mathrm{L}$, and eutrophic waters of $5-50 \mathrm{mg} / \mathrm{L}$. The graph for measuring water nitrate levels is shown in Figure 2.

Different results were shown by the phosphate parameter where the highest value was obtained in the first sampling, which was $0.6 \mathrm{mg} / \mathrm{l}$. Based on PP No. 82 of 2001 concerning Water Quality Management and Pollution Control on the classification and criteria of class II wastewater quality standards, the threshold value of phosphate in fresh water is $0.02 \mathrm{mg} / \mathrm{L}$. According to Permatasari et al. (2016) that the value of phosphate concentration in a water is said to be optimum for plankton growth if it ranges from 0.09 to $1.80 \mathrm{mg} / \mathrm{l}$. This shows that from three repetitions carried out at two stations, only at station 1 the third sampling has a less than optimal value because it is only $0.01 \mathrm{mg} / \mathrm{l}$. Phosphate compounds can come from natural sources such as weathering of plants, soil erosion and anthropogenic activities that produce waste (Rumanti et al., 2014). The results of the measurement of phosphate levels in the waters are shown in Figure 3.
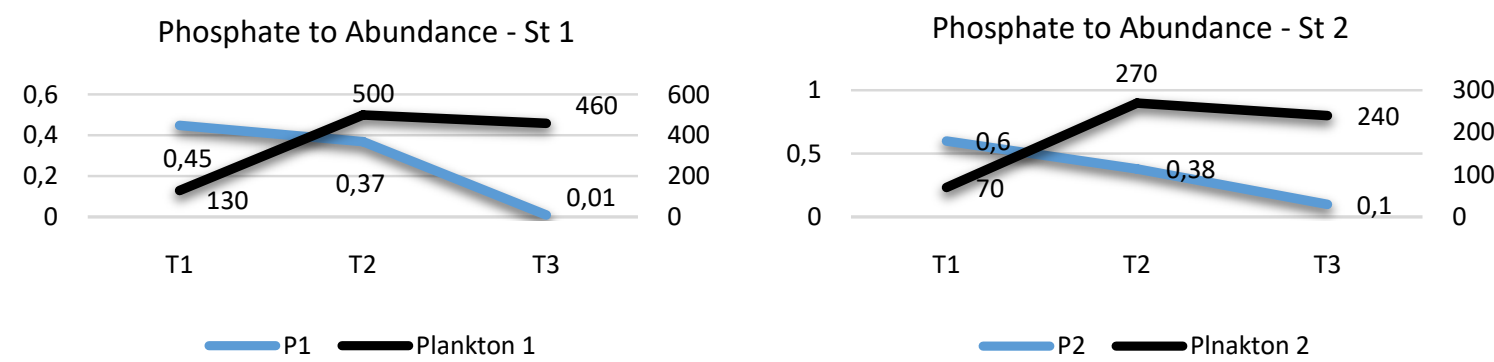

Figure 3 - Results of measuring phosphate levels in waters

Table 6 - Observations of the phytoplankton sampling community I

\begin{tabular}{|c|c|c|c|c|}
\hline \multirow{2}{*}{ No } & \multirow{2}{*}{ Phyllum } & \multirow{2}{*}{ Genera } & \multicolumn{2}{|l|}{ Sample Code } \\
\hline & & & ST-1 Ulu Benteng & ST-2 Rumpiang \\
\hline \multicolumn{5}{|c|}{ Phytoplankton } \\
\hline \multirow[t]{4}{*}{1} & Chloropyta & Closterium & 20 & 10 \\
\hline & & Chara $s p$ & 20 & 10 \\
\hline & & Microspora & 10 & 10 \\
\hline & & Gonatozygon & - & 10 \\
\hline \multirow[t]{4}{*}{2} & Chrysophyta & Pleurosigma & 30 & - \\
\hline & & Coconeis & - & 20 \\
\hline & & Surirella & 20 & - \\
\hline & & Synedra & 30 & 10 \\
\hline \multicolumn{3}{|c|}{ Abundance (Cells/liter) } & $1 \overline{130}$ & 70 \\
\hline \multicolumn{3}{|c|}{ Diversity Index (Shannon-Wiener) } & 1.7380 & 1.7479 \\
\hline \multicolumn{3}{|c|}{ Uniformity Index } & 0.9700 & 0.9755 \\
\hline \multicolumn{3}{|c|}{ Dominance Index } & 0.1834 & 0.1837 \\
\hline \multicolumn{3}{|c|}{ Number of Taxa } & 6 & 6 \\
\hline
\end{tabular}

Based on the results of the study showed that the value of nitrate and phosphate in the downstream Barito river is higher than in the upstream area. This is thought to be influenced by the existence of floating net cages (KJA) either upstream or downstream of the river. Feeding the KJA results in poor water quality (Sukadi, 2010). Fishery activities such as marine cages will leave a build-up of leftover feed on the bottom of the water. This causes the nutrient content to increase and accelerates eutrophication in the waters (Pujiastuti et al., 2013). The presence of KJA in the upstream of the river is thought to cause a higher accumulation of leftover feed downstream because it is carried by river water so that the nitrate and phosphate values in the downstream are relatively high. The high content of organic matter in the waters can cause low levels of dissolved oxygen and increase ammonia in the water column. 
Sampling 1 is the first data collection conducted in April in the upstream and downstream areas of the Barito River. The results of observations made in sampling 1 indicate the presence of a plankton community as shown in Table 6.

The results of the calculation of the abundance of phytoplankton ranged from 70-130 ind/L which indicated the category of low abundance. According to Madinawati (2010), abundance with a value of $<1,000 \mathrm{ind} / \mathrm{L}$ is in the low category, $1,000-40,000 \mathrm{ind} / \mathrm{L}$ is in the medium category, and abundance $>4,000 \mathrm{ind} / \mathrm{L}$ is in the high category. Based on the calculation of the highest abundance value found at station 1. Phytoplankton diversity index values ranged from 1.7380-1.7479. According to the statement (Fachrul, 2007) the diversity index with a value of $1<\mathrm{H}^{\prime}<3$ indicates a moderate level of diversity where the biota community has moderate stability. The uniformity index shows a value ranging from 0.9700 to 0.9755 which means a high level of evenness. According to the statement (Hariyanti \& Wijaya, T. S, 2009), the uniformity index value ranging from 0.6-1 indicates the level of uniformity between species is relatively the same. The results of the phytoplankton dominance index ranged from $0.1834-0.1837$. This value indicates a low dominance category, meaning that there is no type of phytoplankton that dominates at the study site. Based on Fachrul (2007) the dominance index $<0.5$ means that there is no dominant species. The closer to 0 there is no species that dominates the other species. The composition of the plankton community in the Barito River in sampling I is shown in Figure 4.

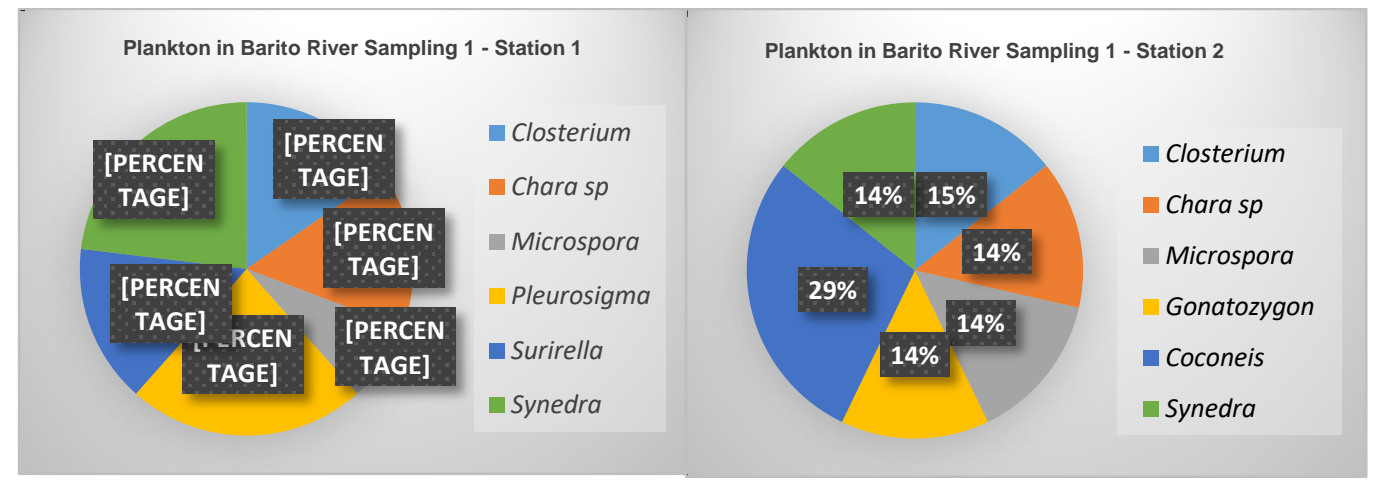

Figure 4 - Composition of plankton sampling I

Table 7 - Observations of the phytoplankton sampling community II

\begin{tabular}{|c|c|c|c|c|}
\hline \multirow[b]{2}{*}{ No } & \multirow[b]{2}{*}{ Phyllum } & \multirow[b]{2}{*}{ Genera } & \multicolumn{2}{|l|}{ Sample Code } \\
\hline & & & $\begin{array}{l}\text { ST-1 } \\
\text { Ulu Benteng }\end{array}$ & $\begin{array}{l}\text { ST-2 } \\
\text { Rumpiang } \\
\end{array}$ \\
\hline \multicolumn{5}{|c|}{ Phytoplankton } \\
\hline \multirow[t]{2}{*}{1} & Cyanophyta & Spirulina & 20 & - \\
\hline & & Oscillatoria & 220 & - \\
\hline 2 & Cyanobacteria & Arthrospira $s p$ & 10 & - \\
\hline 3 & Charophyta & Roya & 100 & - \\
\hline \multirow{5}{*}{4} & Chloropyta & Closterium & & 250 \\
\hline & & Epiphytic oedogonium & 80 & - \\
\hline & & Spirogyra & 20 & - \\
\hline & & Sorastrum pediastriforme & 50 & - \\
\hline & & Gonatozygon & - & 20 \\
\hline \multicolumn{3}{|c|}{ " Abundance (Cells/liter) } & 500 & 270 \\
\hline \multicolumn{3}{|c|}{ Diversity Index (Shannon-Wiener) } & 1.5423 & 0.2641 \\
\hline \multicolumn{3}{|c|}{ Uniformity Index } & 0.7926 & 0.3809 \\
\hline \multirow{2}{*}{\multicolumn{3}{|c|}{ Dominance Index }} & 0.2728 & $\begin{array}{ll}0.8628 \\
\end{array}$ \\
\hline & \multicolumn{2}{|c|}{ Number of Taxa } & $\begin{array}{ll}7 \\
\end{array}$ & 2 \\
\hline
\end{tabular}

Figure 4 shows that there are several different types of plankton between station 1 and station 2. At station 1 the types of plankton that have the highest percentage are Pleurosigma and Synedra at $23 \%$. Synedra is a plankton that has the ability to survive in a less favorable environment, such as the low nutrient content in these waters (Isti'anah et al., 
2015). In addition, Synedra also includes plankton that has a high abundance and can be found in various habitats.

At station 2, the plankton that has the highest percentage is the Coconel species with a percentage of $29 \%$. Cocconeis is a species found in waters with sufficient oxygen and includes cosmopolitan epiphytes, which are in waters with moderate mineral conditions and brackish conditions (Sari et al., 2018).

Sampling II is the second data collection conducted in May in the upstream and downstream areas of the Barito River. The results of observations made in sampling II indicate the presence of a plankton community as shown in Table 7.

Phytoplankton calculation results ranged from $270-500$ ind/L which indicates a low category. Based on the highest values found at station 1 . The phytoplankton diversity index value at station 1 is 1.5423 , the phytoplankton community has a moderate stability category. While at station 2 the diversity index shows a value of 0.2641 where the value is less than 1 which means the phytoplankton community at station 2 is unstable. The uniformity index shows a significant value between stations 1 and 2 . The uniformity index for station 1 shows a value of 0.7926 , which means the level of uniformity between phytoplankton genera is relatively even. While at station 2 the uniformity index shows a value of 0.3809 which means the uniformity between genera is very much different. The results of the phytoplankton dominance index at station 1 show a value of 0.2728 where no species dominates at that location. While at station 2 the dominance index shows a value of more than 0.5 which means that there are species that dominate in that location. The composition of the plankton community in the Barito River in sampling II is shown in Figure 5.

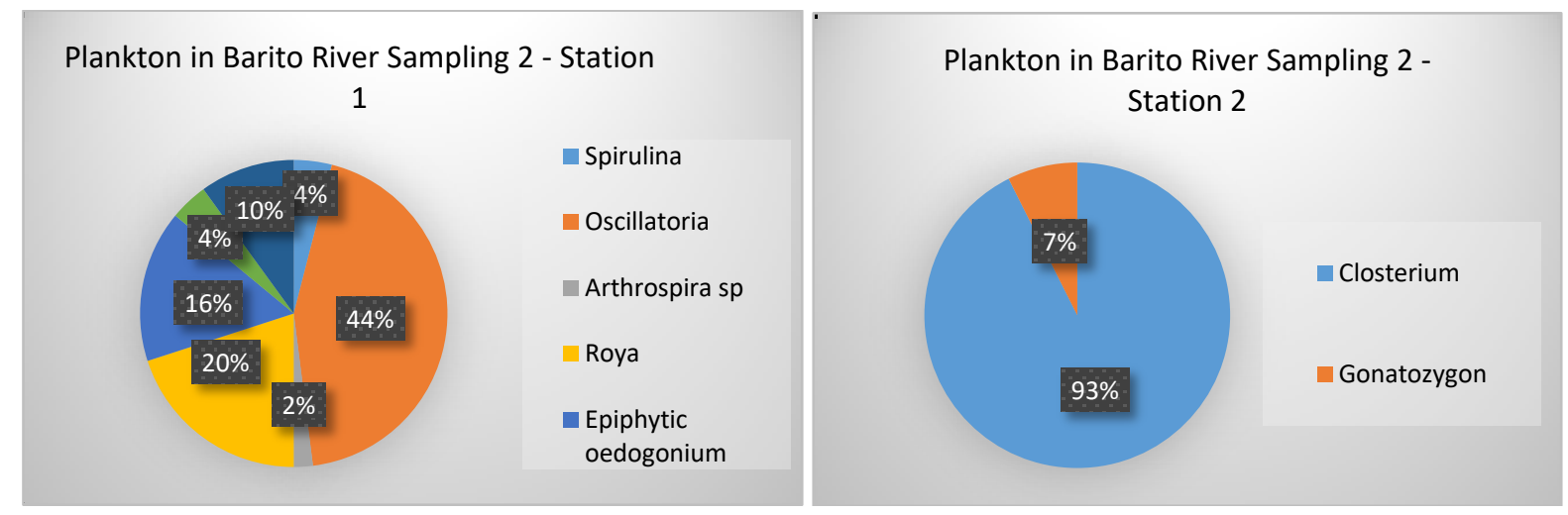

Figure 5 - Composition of plankton sampling II

Figure 5 shows that there are several different types of plankton between station 1 and station 2. At station 1 the type of plankton that has the highest percentage is Oscillatoria with a percentage reaching 44\%. According to Ardiansyah et al. (2017) this plankton is a type that has a high tolerance for pollutants and an unfavorable or polluted environment. Oscillatoria is also one of the species capable of capturing N2 from the air and then immediately reduced to produce $\mathrm{NH} 3+$.

The types of plankton found at station 2 only consisted of 2 species, where Gonatozygon dominated with a percentage of $93 \%$. Gonatozygon is a type of plankton that can survive in various water conditions. This result is in accordance with the statement of Panggabean (2017) that this type of plankton has a wide tolerance range to physical and chemical factors of waters, so that it is able to survive in various environmental conditions.

Sampling III is the second data collection conducted in June in the upstream and downstream areas of the Barito River. The results of observations made in sampling III showed the presence of a plankton community as shown in Table 8.

The results of the calculation of the abundance of phytoplankton ranged from 240-460 ind/L which indicated the low abundance category. Based on the calculation of the highest abundance value found at station 1. Phytoplankton diversity index values ranged from 1.1269-1.4143. According to the statement (Fachrul, 2007) the diversity index with a value of 
$1<\mathrm{H}^{\prime}<3$ indicates the level of biota community has moderate stability. The uniformity index shows values ranging from 0.6801 to 0.8129 , which means that the uniformity between species is relatively even. The results of the phytoplankton dominance index at both stations showed a value of less than 0.5 , namely 0.3620 at station 1 and 0.3750 at station 2 . This value means that there is no dominant species at both stations. The composition of the plankton community in the Barito River in sampling III is shown in Figure 6.

Table 8 - Hasil Observations of the phytoplankton sampling community III

\begin{tabular}{|c|c|c|c|c|}
\hline \multirow[b]{2}{*}{ No } & \multirow[b]{2}{*}{ Phyllum } & \multirow[b]{2}{*}{ Genera } & \multicolumn{2}{|l|}{ Sample Code } \\
\hline & & & $\begin{array}{l}\text { ST-1 } \\
\text { Ulu Benteng } \\
\end{array}$ & ST-2 Rumpiang \\
\hline \multicolumn{5}{|c|}{ Phytoplankton } \\
\hline 1 & Cyanophyta & Oscillatoria & 10 & - \\
\hline \multirow[t]{2}{*}{2} & Chloropyta & Chara & 50 & - \\
\hline & & Dispora crucigenoides & 30 & 120 \\
\hline \multirow[t]{6}{*}{3} & Chrysophyta & Cymbella & - & 20 \\
\hline & & Cymatopleura & 10 & - \\
\hline & & Diatoma & 70 & 20 \\
\hline & & Mougeotiopsis & 20 & - \\
\hline & & Nitzschia & 260 & 80 \\
\hline & & Synedra & 10 & - \\
\hline \multicolumn{3}{|c|}{ Abundance (Cells/liter) } & 4460 & 240 \\
\hline \multicolumn{3}{|c|}{ Diversity Index (Shannon-Wiener) } & $\overline{c 1.4143}$ & 1.1269 \\
\hline \multicolumn{3}{|c|}{ Uniformity Index } & (0.6801 & 0.8129 \\
\hline \multicolumn{3}{|c|}{ Dominance Index } & 0.3620 & 0.3750 \\
\hline \multicolumn{3}{|c|}{ Number of Taxa } & 8 & 4 \\
\hline
\end{tabular}

Plankton in Barito River Sampling 3 - Station

1

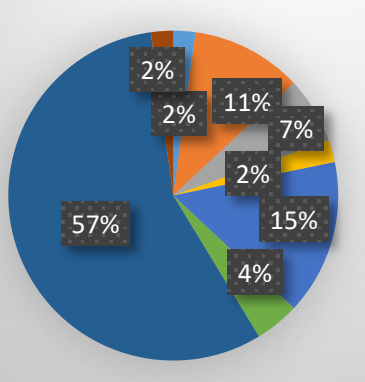

Oscillatoria

- Chara

Dispora

crucigenoides

Cymatopleura

Diatoma

Mougeotiopsis
Plankton in Barito River Sampling 3 Station 2

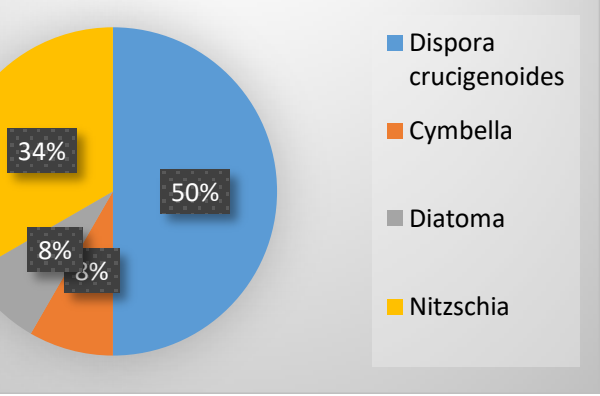

Figure 6 - Composition of plankton sampling III

Figure 6 shows that there are several different types of plankton between station 1 and station 2. At station 1 the plankton that has the highest percentage is Nitzschia with a percentage reaching $57 \%$. At station 2 there are 4 types of plankton which are dominated by Dispora crucigenoides with a percentage of up to $50 \%$. Nitzschia is a periphyton capable of optimally utilizing environmental conditions and nutrients in the waters (Sibarani et al., 2020).

Nitrate levels in the waters will have an effect on the abundance of plankton because it is the main food source. According to Handoko et al. (2013) that the distribution pattern of plankton shows a relationship with the distribution of nitrate in the waters. The following is the result of the calculation of the correlation between nitrate levels and the abundance of plankton as shown in Figure 7. 
Station 1

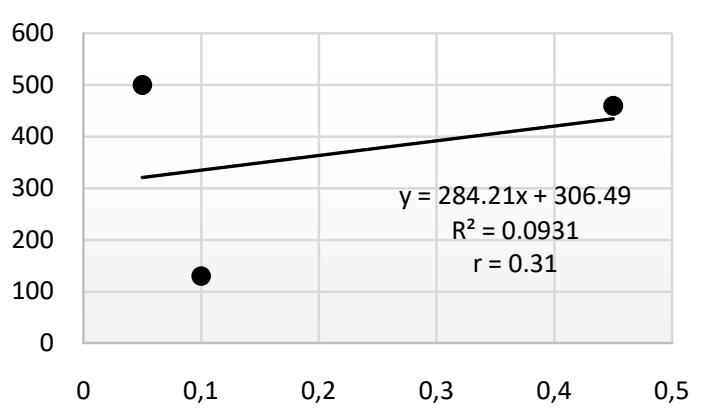

Station 2

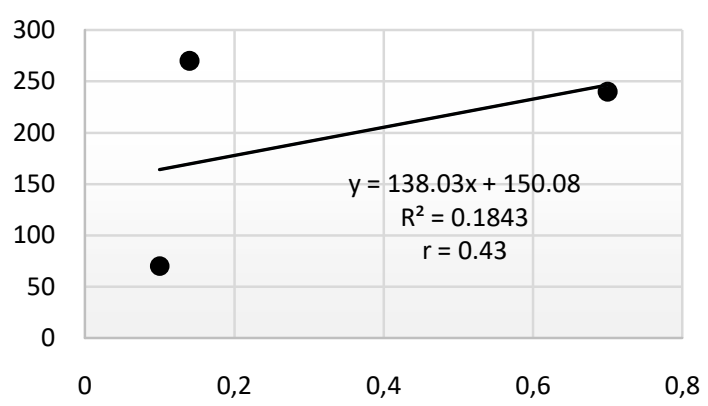

Figure 7 - Correlation of nitrate to plankton abundance

Figure 7 shows that the correlation coefficient value $r=0.31$ for station 1 and $r=0.43$ at station 2. According to Suyitno and Heriawati (2015) that the correlation coefficient value close to zero $(<0.5)$ indicates that the influence of the independent variable (nitrate) on the dependent variable (abundance) is getting smaller. These results indicate that the effect of the nitrate parameter does not have a major influence on the abundance of plankton. According to Permatasari et al. (2016) that the influence of nutrients on the abundance of plankton is not always followed by an increase in the abundance of plankton. This is due to the composition of nutrients that are not in accordance with the needs of plankton.

According to (Sugiyono, 2005), that the level of relationship between variables is divided into five categories, namely $0.00-0.199$ very low relationship, $0.20-0.399$ low relationship, 0.40-0.599 moderate relationship, 0.60-0.799 strong relationship, and 0.80-1.00 the relationship is very strong. The $\mathrm{R} 2$ test that has been carried out shows a result of 0.09 which indicates the presence of phytoplankton in the upper Barito River is influenced by nitrate with a percentage of $9 \%$ while the rest is influenced by other factors. The results of the R2 test at station 2 show a value of 0.18 which means that the presence of plankton in the upper Barito River is influenced by nitrate with a percentage of $18 \%$ while the rest is influenced by other factors.

The presence of phosphate in the waters is often used as a key factor in determining the level of fertility which is then widely used for the life of aquatic biota, one of which is the plankton community. The following is the result of the correlation between water phosphate levels and the abundance of plankton as shown in Figure 8.

Station 1

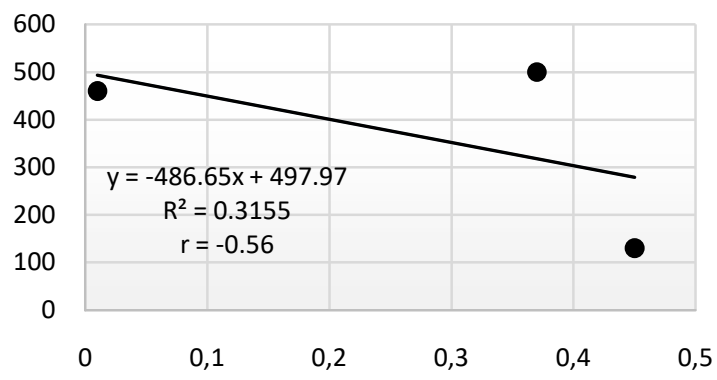

Station 2

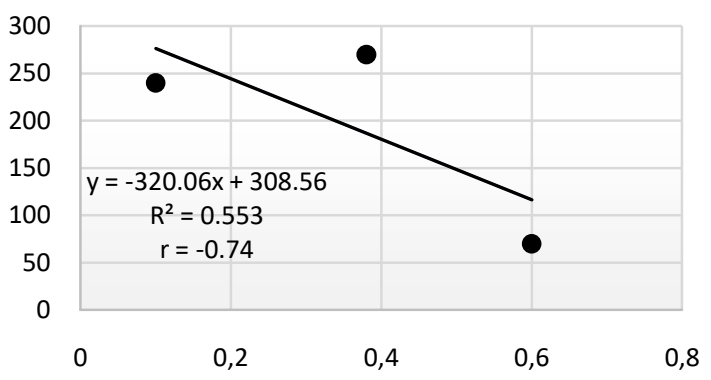

Figure 8 - Correlation of phosphate to plankton abundance

Figure 8 shows that the value of the correlation coefficient $r=-0.56$ at station 1 and $r=$ - 0.74 at station 2. This indicates that phosphate has a strong influence on the abundance of plankton in the Barito River both at station 1 and station 2. This result is strengthened by Kinasih. et al. (2018) a correlation value close to $1(>0.5)$ either positive or negative indicates that phosphate has a major influence on the abundance of plankton. The negative 
value of the correlation coefficient indicates that there is an inverse relationship, namely the lower the phosphate level, the higher the abundance of plankton in the waters. According to Permatasari et al., (2013) said that the low levels of phosphate in the waters are due to the increasing population of plankton.

The results of the R2 test that have been carried out show a value of 0.31 which means that the presence of phytoplankton in the upstream of the Barito River is influenced by phosphate with a percentage of $31 \%$ while the rest is influenced by other factors. The R2 test which was also carried out at station 2 showed a result of 0.55 which means that the presence of plankton in the lower reaches of the Barito River is influenced by phosphate with a percentage of $55 \%$ and the rest is influenced by other factors. The results of the analysis showed that phosphate compounds had a higher effect on the abundance of phytoplankton than nitrate. Phosphate is an essential element for the formation of proteins and cell metabolism in organisms. Optimal algae growth in water conditions with high phosphate concentrations as a source of nutrients (Ikhsan et al., 2020). The level of the relationship between nitrate and phosphate to the abundance of phytoplankton in the downstream of the river is higher than in the upstream. During the observation, the nutrient content obtained at station 2 (downstream) had a fluctuating concentration value that was in line with or directly proportional to the abundance of phytoplankton. This shows that the nutrient content in the location is well utilized for the growth of phytoplankton.

The availability of food in the environment will have an influence on the fish population through the quality and quantity of food provided. Food is one component that plays an important role in determining population density, population dynamics, growth, reproduction, and fish conditions in the waters (Situmorang et al., 2013). Some types of fish also have the ability to choose the food provided by their habitat. This causes differences in the composition of food in fish even though they are of the same type. The ability of fish to choose food provided by their habitat and hereinafter referred to as the choice index in the Barito River during sampling I is shown in Table 9.

Table 9 - Fish selection index sampling I

\begin{tabular}{|l|l|l|l|}
\hline \multicolumn{4}{|l|}{ Sampling 1, Station 1 } \\
\hline No & Phylum & Genus & E Ikan Lawang \\
\hline 1 & Chloropyta & Microspora & 0.652 \\
\hline 2 & Chrysophyta & Synedra & -0.315 \\
\hline
\end{tabular}

Table 9 shows the value of the fish food choice index at the time of sampling I at station 1. According to Situmorang et al. (2013) that the value of the index of choice has a range between -1 to +1 , i.e. if the value is $0<\mathrm{E}<1$ then the type of food is favored by fish, whereas if the value is $-1<\mathrm{E}<0$ then the type of food is not liked by fish. At station 1 , the type of food favored by the mackerel is phytoplankton of the Microspora type. At station 2, there was no preferred index value $(E)$ due to the absence of plankton in the environment found in the fish's stomach.

Table 10 - Fish selection index sampling II

\begin{tabular}{|c|c|c|c|c|}
\hline \multicolumn{5}{|c|}{ Sampling 2, station 1} \\
\hline No & Phylum & Genus & \multicolumn{2}{|c|}{ E Baung Fish } \\
\hline 1 & Cyanophyta & Oscillatoria & \multicolumn{2}{|c|}{0.249} \\
\hline 2 & Chloropyta & Spirogyra & \multicolumn{2}{|l|}{-0.492} \\
\hline \multicolumn{5}{|c|}{ Sampling 2, Station 2} \\
\hline No & Phylum & Genus & E Baung & E Shrimp \\
\hline 1 & Chloropyta & Closterium & 0.835 & 0.802 \\
\hline
\end{tabular}

The absence of any type of plankton in the environment at the time of sampling found in the fish's stomach indicates that the fish are taking food from other places. This is related to the ability of fish to move freely and actively swim so that they have a wider area in search of food. This is in accordance with the statement of Situmorang et al. (2013) that the choice of fish food preferences is influenced by several factors, namely the distribution of fish 
favorite foods, food availability, and other physical factors such as the area and the condition of the waters. The choice index assessment was also carried out at the time of sampling II as shown in Table 10.

Table 10 shows that at station 1 the favorite food for baung fish is plankton of the Oscillatoria type. While at station II, it shows that there is the same food preference between baung fish and shrimp where Closterium plankton is their favorite food with the value of $E$ not much different, which is around the value of 0.8 . The most organisms found in the waters are not necessarily a food choice for fish, this is because fish have a selective nature in determining their food so that fish can take food from other places according to their preferences (Windy et al., 2014). The last sampling that was carried out was sampling III as shown in Table 11.

Table 11 - Fish selection index sampling III

\begin{tabular}{|c|c|c|c|c|c|}
\hline \multicolumn{6}{|c|}{ Sampling 3, Station 1} \\
\hline \multirow{2}{*}{ No } & \multirow{2}{*}{ Phylum } & \multirow{2}{*}{ Genus } & \multicolumn{3}{|l|}{$E$} \\
\hline & & & Lawang Fish & Sanggang Fish & giant prawns \\
\hline 1 & Cyanophyta & Oscillatoria & 0.30 & 1.00 & 1.00 \\
\hline \multirow[t]{2}{*}{2} & Chloropyta & Chara & 1.00 & 0.51 & 1.00 \\
\hline & & Dispora crucigenoides & 0.70 & 1.00 & 1.00 \\
\hline \multirow[t]{2}{*}{3} & Chrysophyta & Diatoma & -0.59 & 1.00 & 1.00 \\
\hline & & Synedra & 0.96 & 0.45 & 0.51 \\
\hline \multicolumn{6}{|c|}{ Sampling 3, Station 2} \\
\hline \multirow{2}{*}{ No } & \multirow{2}{*}{ Phylum } & \multirow{2}{*}{ Genus } & \multicolumn{3}{|l|}{$\mathrm{E}$} \\
\hline & & & \multicolumn{2}{|l|}{ Sanggang Fish } & giant prawns \\
\hline 1 & Chloropyta & Chara & \multicolumn{2}{|l|}{0.87} & 0.90 \\
\hline 2 & Chrysophyta & Nitzschia & \multicolumn{2}{|l|}{0.33} & 1.00 \\
\hline
\end{tabular}

Table 11 shows the index of fish food choice at station 1, Lawang fish and giant prawns have the same favorite food in the form of plankton from the Synedra species with index values reaching 0.96 for Lawang fish and 0.51 for giant prawns. Another type of fish found, namely grilled fish, has a different favorite food in the form of plankton from the Chara type with an index value of 0.51 . The grilled fish which was also found at station 2 had the same favorite food as the grilled fish at station 1, namely plankton of the Chara species with an index value of 0.87 . Different results were actually shown for giant prawns at the station which had different favorite foods from giant prawns at station 1, namely plankton of the Chara species with an index value of 0.90 .

The differences in fish preferences for types of food are very relative, so that the same fish in different places is very possible to have different favorite foods. The same result was conveyed by Kurnia et al. (2017) that fish's preference for food is influenced by various factors. These factors include the uneven distribution of organisms as fish food, the choice of fish, as well as the physical and chemical factors of the waters that can affect the condition of the waters so that it affects the fish choice index.

\section{CONCLUSION}

Nutrient conditions in Barito River waters show differences between stations and between sampling times. Overall, station 2 which is located downstream of the river has a higher content than station 1, both for nitrate and phosphate parameters. The opposite result is shown in the abundance of plankton in the waters where station 1 has a higher abundance than station 2 at all sampling times. The relationship between the two variables was then carried out by a simple regression test which showed that the nitrate parameter had a linear relationship to the abundance of plankton with a low-medium relationship. Different results are shown by the phosphate parameters where there is an opposite, namely if the phosphate decreases, the abundance of plankton will increase with a moderate-strong relationship. In addition, the results of the analysis of the fish choice index (E) show that fish have a preference for their food. This is evidenced by the presence of some fish eating organisms that are not found in their environment but are found in their stomachs. 


\section{ACKNOWLEDGMENTS}

Acknowledgments are conveyed to the Institute for Research and Community Service at University of Lambung Mangkurat (LPPM ULM) which has funded this research through the PNBP Research Grant Fund on the skin of the 2021 Compulsory Lecturer Program.

\section{REFERENCES}

1. Ambarwati. (2019). Pengaruh Faktor Fisika-Kimia Perairan terhadap Kelimpahan dan Keanekaragaman Plankton di Ekosistem Terumbu Karang Alami dan Buatan Perairan PLTU Paiton. Skripsi. UIN Sunan Ampel Surabaya.

2. Ardiansyah M., Suryanto A., dan Haeruddin. 2017. Hubungan Konsentrasi Minyak dan Fenol dengan Kelimpahan Fitoplankton di Sungai Asem Binatur, Kota Pekalongan. Journal of Maquares. Vol. 6 (1):95-102.

3. Effendi, H. 2003. Telaah Kualitas Air Bagi Pengelolaan Sumberdaya dan Lingkungan Perairan. Kanisius. Yogyakarta.

4. Elfinurfajri, F. 2009. Struktur Komunitas Fitoplankton serta Keterkaitannya dengan Kualitas Perairan di Lingkungan Tambak Udang Intensif. [Skripsi]. Fakultas Perikanan dan Ilmu Kelautan, Institut Pertanian Bogor. Bogor.

5. Fachrul, M. F. (2007). Metode Sampling Bioekologi. Jakarta: Bumi Aksara.

6. Faza, F. (2012). Struktur Komunitas Plankton di Sungai Prasanggrahan dari Bagian Hulu (Bogor, Jawa Barat) hingga Bagian Hilir (Kembangan DKI Jakarta). Laporan Penelitian. Universitas Indonesia.

7. Handoko, M. Yusuf, dan Wulandari S. Y. 2013. Sebaran Nitrat dan Fosfat dalam Kaitannya dengan Kelimpahan Fitoplankton di Kepulauan Karimunjawa. Buletin Oseanografi Marina. Vol 2 (2): 48-53.

8. Ikhsan, M., Siti, R., \& Churun, A. (2020). Hubungan Antara Nitrat dan Fosfat dengan Kelimpahan Fitoplankton di Waduk Jatibarang Semarang. Journal of Maquares, Volume 9, Nomor 01, Halaman 23-30.

9. Isti'anah D., Huda M. F., dan Laily A. N. 2015. Synedra sp. sebagai Mikroalga yang Ditemukan di Sungai Besuki Porong Sidoarjo, Jawa Timur. Jurnal Bioedukasi. Vol 8. (1): 57-59.

10. Kinasih, A. G., Rizqi A. P., dan Misbakhul M. 2018. Studi Hubungan Struktur Komunitas dan Indeks Ekologi Makrobenthos dengan Kualitas Perairan di Rumah Mangrove Wonorejo, Surabaya. Proseding Seminar Nasional Kelautan dan Perikanan IV.

11. Kurnia R., Widyorini N., dan Solichin A. 2017. Analisis Kompetisi Makanan antara Ikan Tawes, Ikan Mujair, dan Ikan Nila di Perairan Waduk Wadaslintang Kabupaten Wonosobo. Jurnal of Maquares. Vol 6 (4): 515-524.

12. Nontji, Anugerah. 2006. Plankton. Jakarta: Pusat Penelitian Oseanografi Lembaga IImu Pengetahuan Indonesia (LIPI Press).

13. Nyibakken, J.W. 1992. Biologi Laut. Suatu Pendekatan Ekologis. Gramedia: Jakarta.

14. Odum, E. P. 1993. Dasar-dasar Ekologi. Edisi ketiga. Terjemahan: Samingan, T., Srigandono. Fundamentals Of Ecology. Third Edition. Gadjah Mada University Press.

15. Odum, E.P. 1996. Dasar-Dasar Ekologi. Gajah Mada University Press, Yogyakarta.

16. Panggabean B. J. 2017. Keanekaragaman Plankton dan Hubungan dengan Faktor Fisika Kimia Perairan di Aliran Sungai Bah Bolon, Kota Pematang Siantar, Sumatera Utara. Skripsi. Medan. Universitas Sumatera Utara.

17. Permatasari R. D., Djuwito, dan Irwani. 2016. Pengaruh Kandungan Nitrat dan Fosfat terhadap Kelimpahan Diatom di Muara Sungai Wulan, Demak. Journal of Maquares. Vol 5 (4): 224-232.

18. Pujiastuti, P., Ismail, B., \& Pranoto. (2013). Kualitas dan Beban Pencemaran Perairan Waduk Gajah Mungkur. EKOSAINS, V(1).

19. Rumanti, M., Siti, R., \& Mustofa, N. (2014). Hubungan Antara Kandungan Nitrat dan Fosfat dengan Kelimpahan Fitoplankton di Sungai Bremi Kabupaten Pekalongan. 
Diponegoro Journal of Management of Aquatic Resources, Volume 3, Nomor 1, Halaman 168-176.

20. Sari D. R., Hidayat J. W., dan Hariyati R. 2018. Struktur Komunitas Plankton di Kawasan Wana Wisata Curug Semirang Kecamatan Ungaran Barat, Semarang. Jurnal Akademika Biologi. Vol. 7 (4):32-37.

21. Sibarani L. B. G., Dahril Tengku, dan Simarmata A. H. 2020. Jenis dan Kelimpahan Perifiton dengan Substrat Bambu di Genangan Kelurahan Batu Bersurat Kabupaten Kampar Riau. Jurnal Sumberdaya dan Lingkungan Akuatik. Vol 1 (1).

22. Situmorang T. S., Barus T. A., dan Wahyuningsih H. 2013.Studi Komparasi Jenis Makanan Ikan Keperas di Sungai Aek Pahu Tombak, Aek Pahu Hotamusu, dan Sungai Parbotikan Kecamatan Batang Toru Tapanuli Selatan. Jurnal Perikanan dan Kelautan. Vol 18 (2): 48-58.

23. Sugiyono. 2005. Analisis Statistik Korelasi Linier Sederhana. Bandung: CV Alfabeta.

24. Sugiyono. 2006. Metode Penelitian Kuantitatif Kualitatif dan R\&D. Bandung: CV Alfabeta

25. Sukadi, M. (2010). Ketahanan dalam Air dan Pelepasan Nitrogen dan Fosfor ke Air Media dari Berbagai Pakan Ikan Air Tawar. Jurnal. Ris. Akuakultur, 5(1): 01-12.

26. Suwondo, Elya Febrita, Dessy dab Mahmud Alpusari. 2004. Kualitas Biologi Perairan Sungai Senapelan, Sago dan Sail di Kota Pekanbaru Berdasarkan Bioindikator Plankton dan Bentos. Universitas Riau. Pekanbaru.

27. Suyitno, P. P. W. dan Heriawati. 2015. Metode Regresi Linear Berganda Kualitas Super Member Supermall terhadap Peningkatan Jumlah Pengunjung pada Supermall Karawang. Bina Insani ICT Journal. Vol. 2 (2): 101-116.

28. Windy, Wahyuningsih H., Suryanti A. 2014. Kebiasaan Makanan Ikan Baung di Sungai Bingai Kota Binjai Provinsi Sumatera Utara. Universitas Sumatera Utara. Medan. 